\title{
HUBUNGAN KECEPATAN DENGAN KEMAMPUAN DRIBBLING ATLET BOLABASKET PUTERA CLUB NEO CLACH BUKITTINGGI
}

\author{
Hendri Neldi \\ Program Studi Pendidikan Jasmani Kesehatan dan Rekreasi Fakultas Ilmu Keolahragaan \\ Universitas Negeri Padang \\ Email : hendrineldi@fik.unp.ac.id
}

\begin{abstract}
ABSTRAK
Problem in this research that is decreasing achievement of athlete of club NEO Clach Bukittinggi, as for research purpose is to know the relation of speed and hand eye coordination to dribbling ability of club basketball athlete of NEO CLACH Bukittinggi. The method of this research is correlation method. The population of this study is all athletes Bolabasket NEO Clach Bukittinggi amounted to 14 people, sampling in this study was done by total sampling technique. So in this study are sampled is 14 people athletes who follow the training of club bolabasket NEO Clach Bukittinggi. This research was conducted in January 2018, while the research place was conducted in SMA 4 N Bukittinggi. Speed data with a 30-meter speed test, eye-hand coordination data of the Neo Clach Bukititinggi basketball athlete, was taken using a throw ball test to the wall and dribbling ability data with a dribbling zig-zag ability test.

The result of data analysis shows that: (1). Speed has a significant relationship to dribbling ability, this is indicated by the results obtained is tcount 2.03> ttabel 1.76 (2). Eye Coordination has a significant relationship to dribbling ability, this is indicated by the result obtained that is tcount 3.48> ttabel 1.76 (3). There is a significant joint relationship between speed and hand-eye coordination with dribbling ability. Obtained Fcount 8.97> Ftable 3.35, with the value $\mathrm{R}=0.736$ obtained $\mathrm{R} 2=0.542$, while the contribution is $54.2 \%$.
\end{abstract}

\section{HUBUNGAN KECEPATAN DAN KOORDINASI MATA-ATANGAN DENGAN KETERAMPILAN MENGGIRING BOLA BASKET ATLET PUTRA KLUB NEO CLACH CLUB BUKITTINGGI}

\begin{abstract}
Abstrak
Permasalahan dalam penelitian ini adalah penurunan prestasi atlet Klub NEO Clach Bukittinggi. Tujuan penelitian ini adalah untuk mengetahui hubungan kecepatan dan koordinasi matatangtan dengan keterampilan menggiring bola basket atlet Klub NEO CLACH Bukittinggi. Metode penelitian korelasi digunakan dalam penelitian ini.Populasi penelitian ini adalah 14 atle tKlub NEO Clach Bukittinggi. Sampelpadapenelitianiniadalah 14 atletKlub NEO ClachBukittinggi yang diambildengantekniktotal sampling. Data kecepatandikumpulkanmelaluiteskecepatan $30 \mathrm{~m}$, data koordinasimata-tangandikumpulkanmelaluitesmelempar bola, dan data kemampuanmenggiring bola basket dikumpulkanmelaluitesmenggiringzig-zag.

Hasildarianalisis data menunjukkanbahwa: (1) kecepatanmemilikihubungan yang signifikandenganketerampilanmenggiring bola basket, haliniditunjukkanpadahasil yang didapatdimanat ${ }_{\text {hitung }} \quad 2.03>\mathrm{t}_{\text {tabel }} \quad 1.76$; (2) Koordinasimata-tanganmempunyaihubungan yang signifikandengankemampuanmenggiring bola basket, haliniditunjukkanpadahasil yang didapatdimanat ${ }_{\text {hitung }} \quad 3.48>\quad \mathrm{t}_{\text {tabel }} \quad 1.76$; $\quad$ (3) Terdapathubungan yang signifikanantarakecepatandankoordinasimata-tangandengankemampuanmenggiring bola basket. Hasilpenelitianinijugamendapatkan $F_{\text {hitung }} 8.97>F_{\text {tabel }} 3.35$, dengannilai $R_{\text {hitung }}=0.736$ and $R_{\text {tabel }}=0.542$, sedangkannilaikontribusiadalah $54.2 \%$.
\end{abstract}

Kata kunci: Kecepatan, Koordinasimata-tangan, Menggiring, Bola Basket 


\section{PENDAHULUAN}

Bolabasket merupakan cabang olahraga yang makin banyak digemari oleh masyarakat terutama dari kalangan pelajar dan mahasiswa, ini terbukti dengan munculnya klub-klub tangguh di tanah air dan atlet-atlet bolabasket baik tingkat sekolah maupun perguruan tinggi ditunjang lagi dengan sering diadakannya pertandingan-pertandingan antar klub, antar pelajar tingkat daerah maupun nasional.

Salah satu bentuk tujuan olahraga bolabasket adalah pencapaian prestasi yang maksimal yang juga tak luput dari perhatian pemerintah dalam pengembangan olahraga prestasi. Salah satu bentuk perhatian pemerintah dalam pengembangan olahraga prestasi di Indonesia telah dijabarkan dalam UU Republik Indonesia No. 3 tahun 2005 tentang sistem Keolahragaan Nasional, dalam pasal 20 ayat 2 dan 3 menjelaskan bahwah :

Ayat 2: Olahraga prestasi dilakukan oleh setiap orang yang memiliki bakat, kemampuan dan potensi untuk mencapai prestasi. Ayat 3: Olahraga prestasi dilaksanakan melalui pembinaan dan pengembangan secara terencana, berjenjang dan berkelanjutan dengan dukungan ilmu pengetahuan dan teknologi keolahragaan.

Dari uraian di atas dapat dilihat bahwa

prestasi olahraga bolabasket Indonesia harus di dukung oleh pembinaan dan pengembangan secara terencana, olahraga bolabasket merupakan cabang olahraga yag rumit dan kompleks, karena sangat banyak faktor yang mempengaruhui untuk mencapai prestasi yang maksimal. Bolabasket juga mempunyai ide permainan yakni memasukkan bola sebanyak mungkin kedalam ring basket lawan dan mempertahankan ring basket sendiri dari ancaman lawan.

Olahraga bola basket berkembang di klub NEO CLACH , berdiri sejak tahun 1999, tim bola basket NEO CLACH sendiri di dalamnya merupakan masyarakat umum yang kebanyakan berisisiswa-siswa SMP dan SMA yang dipersiapkan untuk Popda, Porseni, Kejurda, dan DBL baik putri maupun putra. Pada kejuaraan antar klub sendiri tim NEO CLACHpernah menjadi juara I Walikota Cup Bukittinggi tahun 2012,dan sering masuk final pada tahun 2013 sd 2015 di kejuaraan basketball putra di Bukittinggi.

Namun akhir-akhir ini prestasi atlet putera NEO CLACH mulai turun. Disisi lain kemampuan dribbling atlet mulai menurun atau belum maksimal. Hal ini dapat dilihat sewaktu bertanding, bola dengan mudahnya direbut lawan sewaktu mendrible. Disisi lain banyak hal yang menjadi persoalan dalam buruknya prestasi 
atlet basket klub NEO CLACH, secara fakta dan data raihan juara masih jauh dari yang diharapkan. Berdasarkan penjelasan serta masalah yang ada menurut informasi pelatih dan pengamatan peneliti melalui observasi terdapat beberapa faktor yang mempengaruhi penurunan prestasi klub NEO CLACH yaitu antara lain:Motivasi atlet dalam mengikuti program latihan, sarana dan prasarana yang minim,kurangnya atlet memperhatikan gizi,koordinasi yang kurang, kurangnya kondisi fisik atlet,lemahnya mental atlet serta kemampuan teknik yang masih kurang.

Jika hal ini dibiarkan maka akan mengakibatkan prestasi tim atlet bola basket putra klub NEO CLACH bukittinggi akan menurun, oleh karena itu penulis tertarik untuk mengangkat judul penelitian yaitu: "Hubungan

Kecepatan dan koordinasi mata tangan terhadap kemampuan dribling atlet bola basket putra klub NEO CLACH BUKITTINGGI."

\section{METODOLOGI PENELITIAN}

1. Berdasarkan pada hipotesis yang diajukan, analisis data yang dilakukan untuk melihat hubungan antar variabel dengan menggunakan statistik analisis korelasi product moment pada taraf signifikan 0,05 oleh Pearson dalam Sudjana (1992:382), rumus tersebut adalah :

$$
r_{x y}=\frac{n \sum X Y-\left(\sum X\right)\left(\sum Y\right)}{\sqrt{\left\{n \sum X^{2}-\left(\sum X\right)^{2}\right)\left\{n \sum Y^{2}-\left(\sum Y\right)^{2}\right\}}}
$$

2. Untuk mengetahui apakah yang telah dihitung melalui koefisien itu signifikan atau tidak, maka perlu dilakukan langkah mencari uji signifikansi korelasi dengan rumus :

$$
\mathrm{t}=\frac{\mathrm{r} \sqrt{\mathrm{n}-2}}{\sqrt{1-\mathrm{r}^{2}}}
$$

Dengan kriteria sebagai berikut :

$$
-\mathrm{t}(1-1 / 2 \alpha)<\mathrm{t}(1-1 / \alpha)
$$

3. Sedangkanuntukmelihatketigahubunganvaria belmenggunakanrumuskorelasiganda.

Menurut (Fardi, 2010:35), rumus yang digunakanadalahsebagaiberikut :

$$
\begin{aligned}
& \text { Ry. } \mathrm{X}_{1} \cdot \mathrm{X}_{2} \\
& \sqrt{\frac{r^{2} y 1+r^{2} y 2-2 r y 1 r y 2 r 12}{1-r^{2} 12}}
\end{aligned}
$$

4. UjisignifikanMultipleKorelation

(korelasiganda) untukmengetahuiapakah antara variabel yang telah di hitungsignifikanatautidak, maka di lakukanlangkah-

langkahmencariujisignifikanmultipledenganr umussebagaiberikut :

$$
\mathrm{F}=\frac{R^{2} / K}{\left(1-R^{2}\right) /(N-K-1)}
$$


5. Untuk mengetahui besarnya hubungan kecepatandan koordinasi mata-tangan terhadap kemampuan dribbling atlet bola basket putra klub Neo CLACH BUKITTINGGIi, maka ditentukan melalui koefisian determinasi dengan rumus:

$$
\mathrm{Kd}=\mathrm{r}^{2} \times 100 \%
$$

(Arikunto, 2010:369)

\section{HASIL DAN PEMBAHASAN}

\section{HASIL}

\section{a. Kecepatan}

Berdasarkan data penelitian untuk skor Kecepatan, diperoleh skor terendah $6,8 \mathrm{~s}$ dan skor tertinggi 4,01 s. Dari analisis data didapatkan harga ratarata (mean) sebesar 5,06, Simpangan baku (standar deviasi) 0,81. Distribusi frekuensi Kecepatan sebagaimana tampak pada Tabel berikut ini:

Tabel. 1

Distribusi Frekuensi Data Kecepatan

\begin{tabular}{|c|c|c|c|}
\hline \multirow[b]{2}{*}{ No } & \multirow{2}{*}{$\begin{array}{l}\text { Kelas } \\
\text { Interval }\end{array}$} & \multicolumn{2}{|c|}{ Frekuensi } \\
\hline & & FA & FR \\
\hline 1 & $4,01-4,56$ & 5 & 35.71 \\
\hline 2 & $4,57-5,12$ & 4 & 28.57 \\
\hline 3 & $5,13-5,68$ & 2 & 14.29 \\
\hline 4 & $5,69-6,23$ & 2 & 14.29 \\
\hline 5 & $6,24-6,80$ & 1 & 7.14 \\
\hline & JUMLAH & 14 & 100 \\
\hline
\end{tabular}

Berdasarkan perhitungan yang tertera pada Tabel 3 dapat dilihat bahwa: 5 orang atau $(35,71 \%)$ berada pada kelas interval $4,10-4,56,4$ orang atau $(28,57 \%)$ berada pada kelas interval $4,57-5,12,2$ orang atau $(14,29 \%)$ berada pada kelas interval 5,13-5,68, 2 orang atau $(14,29 \%)$ berada pada kelas interval 5,69-6,23, 1 orang atau $(7,14 \%)$ berada pada kelas interval 6,24-6,80. Untuk lebih jelasnya, distribusi frekuensi skor Kecepatan juga dapat dilihat pada histogram di bawah ini :

\section{Grafik1.}

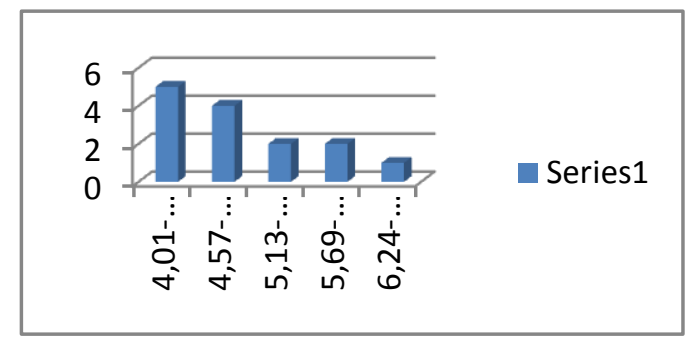

Histogram Data Kecepatan $\left(\mathbf{X}_{1}\right)$

\section{b. Dribbling (Y)}

Berdasarkan data penelitian

untuk skor Kemampuan Dribbling, diperoleh skor tercepat $8,97 \mathrm{~s}$ dan skor terlama 13 s. Dari analisis data didapatkan harga rata-rata (mean) sebesar 10,54, Simpangan baku (standar deviasi) 1,40. Distribusi frekuensi skor Kemampuan Dribbling, sebagaimana tampak pada Tabel berikut ini:

Tabel.3

Distribusi Frekuensi DataKemampuan Dribbling

\begin{tabular}{|l|l|l|}
\hline No & Kelas Interval & Frekuensi \\
\hline
\end{tabular}




\begin{tabular}{|c|c|c|c|}
\hline & & FA & FR \\
\hline 1 & $8,97-9,77$ & 5 & 35.71 \\
\hline 2 & $9,78-10,58$ & 4 & 28.57 \\
\hline 3 & $10,59-11,39$ & 2 & 14.29 \\
\hline 4 & $11,40-12,20$ & - & - \\
\hline 5 & $12,21-13,01$ & 3 & 21.43 \\
\hline & JUMLAH & 14 & 100 \\
\hline
\end{tabular}

Berdasarkan perhitungan yang tertera pada Tabel 5 dapat dilihat bahwa: 5 orang atau $(35,71 \%)$ berada pada kelas interval 8,97-9,77, 4 orang atau $(28,57 \%)$ berada pada kelas interval $9,78-10,58,2$ orang atau $(14,29 \%)$ berada pada kelas interval $10,59-11,39,3$ orang atau $(21,43 \%)$ berada pada kelas interval 12,2113,01. Untuk lebih jelasnya, distribusi frekuensi skor Kemampuan Dribbling juga dapat dilihat pada histogram di bawah ini :

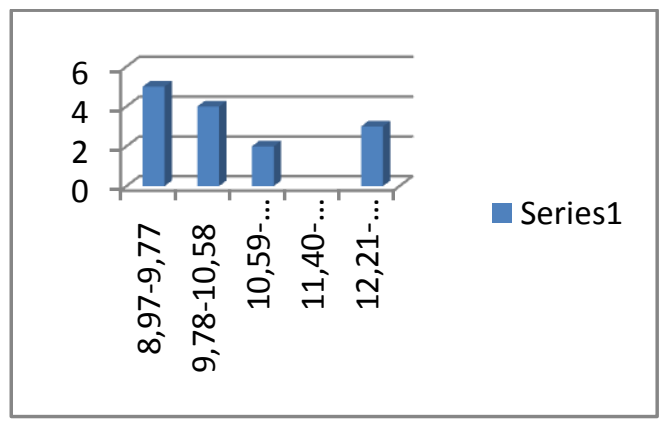

Grafik. 3

\section{Histogram Data Kemampuan} Dribbling (Y)

Berikut ini disajikan hasil pengujian terhadap ketiga hipotesis penelitian yang telah diajukan di atas.

\section{Hipotesis Satu}

Terdapat Hubungan yang Signifikan Antara Kecepatan dengan Kemampuan Dribbling

\begin{tabular}{|c|l|l|c|c|}
\hline Korelasi & Koefisi & Koefisien & $\mathrm{t}-$ & $\begin{array}{c}\mathrm{t}- \\
\text { enKore }\end{array}$ \\
Antara & Determinas & hitun & tabel \\
& lasi(r) & $\mathrm{i}\left(\mathrm{r}^{2}\right)$ & $\mathrm{g}$ & $\alpha=$ \\
& & & & 0,05 \\
\hline $\mathrm{X}_{2}$ dan $\mathrm{Y}$ & 0,707 & 0,500 & 3,48 & 1,76 \\
\hline
\end{tabular}

AtletBolabasket Putra Klub NEO CLACH BukitTinggi

Analisis korelasi terhadap Kecepatan dengan Kemampuan Dribbling menghasilkan koefisien korelasi sebesar $\mathrm{r}_{\mathrm{y} 1}=0,506$. Untuk uji keberartian koefisien korelasi disajikan pada tabel berikut ini.

Tabel 4. Rangkuman Hasil Analisis Korelasi antara Kecepatan dengan Kemampuan Dribbling

\begin{tabular}{|c|c|c|c|c|}
\hline $\begin{array}{c}\text { Korelasi } \\
\text { Antara }\end{array}$ & $\begin{array}{l}\text { Koefisien } \\
\text { orelasi(r) }\end{array}$ & $\begin{array}{c}\text { Koefisien } \\
\text { Determinas } \\
\mathrm{i}\left(\mathrm{r}^{2}\right)\end{array}$ & $\begin{array}{l}\mathrm{t}- \\
\text { hitun } \\
\mathrm{g}\end{array}$ & $\begin{array}{c}\mathrm{t}- \\
\text { tabel } \\
\alpha \square=0 \\
, 05\end{array}$ \\
\hline $\mathrm{X}_{1}$ dan $\mathrm{Y}$ & 0,506 & 0,256 & 2,03 & 1,76 \\
\hline
\end{tabular}

Keterangan:

Koefisien korelasi signifikan $\left(t_{\text {hit }}=2,03>t_{\text {tab }}=\right.$ 1,76)

Berdasarkan uji keberartian korelasi antara pasangan skor Kecepatan $\left(\mathrm{X}_{1}\right)$ dengan Hasil kemampuan dribbling (Y) sebagaimana terlihat pada Tabel $7 \mathrm{di}$ atas diperoleh $\mathrm{t}_{\text {hitung }}=$ $2,03>\mathrm{t}_{\text {tabel }}=1,76$ pada taraf signifikansi $\alpha \square=$ 0,05 . Dengan demikian, $\mathrm{H}_{\mathrm{a}}$ yang mengatakan bahwa Terdapat hubungan yang signifikan antara Kecepatan dengan kemampuan dribbling Atlet Bolabasket Putra Klub NEO CLACH BukitTinggi diterima, konsekuensinya $\mathrm{H}_{0}$ ditolak. Temuan ini menyimpulkan bahwa 
terdapat hubungan yang berarti antara Kecepatan dengan kemampuan dribbling Atlet Bolabasket Putra Klub NEO CLACH BukitTinggi.

\section{Hipotesis Dua}

Terdapat Hubungan yang Signifikan Antara Koordinasi Mata Tangan dengan Kemampuan Dribbling AtletBolabasket Putra Klub NEO CLACH BukitTinggi.

Analisis korelasi antara kemampuan Koordinasi Mata Tangan dengan Kemampuan Dribbling menghasilkan koefisien korelasi sebesar $r_{y 2}=0,707$. Untuk uji keberartian koefisien korelasi disajikan pada tabel berikut ini:

Tabel 5. Rangkuman Hasil Analisis Korelasi antara Kemampuan Koordinasi Mata Tangan dengan Kemampuan Dribbling

Keterangan:

Koefisien korelasi tidak signifikan $\left(t_{h i t}=3,48>\right.$ $\left.\mathrm{t}_{\mathrm{tab}}=1,76\right)$

Berdasarkan uji keberartian korelasi antara pasangan skor Kemampuan Koordinasi Mata Tangan $\left(\mathrm{X}_{2}\right)$ dengan Kemampuan Dribbling (Y) sebagaimana terlihat pada Tabel 8 diperoleh $t_{\text {hitung }}=3,48>t_{\text {tabel }} 1,76$ pada taraf signifikansi $\alpha$ $=0,05$. Dengan demikian, $\mathrm{H}_{\mathrm{a}}$ yang mengatakan bahwa Terdapat hubungan yang signifikan antara Koordinasi Mata Tangan dengan kemampuan dribbling Atlet BolaBasket Putra Klub NEO CLACH BukitTinggi diterima, konsekuensinya $\mathrm{H}_{0}$ ditolak. Temuan ini menyimpulkan bahwa Terdapat hubungan yang berarti antara Koordinasi Mata Tangan dengan kemampuan dribbling Atlet Bolabasket Putra Klub NEO CLACH BukitTinggi.

Selanjutnya untuk menentukan besarnya kontribusi Koordinasi Mata Tangan terhadap Kemampuan Dribbling ditunjukkan darihasil analisis koefisien determinasinya yaitu sebesar $r^{2}$ $=0,499$. Hal ini berarti variabel Koordinasi Mata Tanganmemberi kontribusi sebesar 49,9 \% terhadap Kemampuan Dribbling.

3. Hipotesis Tiga

Terdapat Hubungan yang Signifikan antara Kecepatan dan Koordinasi Mata Tangan secara Bersama-Sama dengan Kemampuan Dribbling AtletBolabasket Putra Klub NEO CLACH BukitTinggi.

Analisis korelasi terhadap Kecepatan dan Koordinasi Mata Tangan Secara BersamaSama dengan kemampuan dribbling Atlet Bolabasket Putra Klub NEO CLACH BukitTinggi menghasilkan korelasi ganda sebesar 0,736. Untuk uji keberartian koefisien korelasi disajikan pada tabel berikut ini.

Tabel 6. Rangkuman Hasil Analisis Korelasi Ganda antara Kecepatandan Koordinasi Mata TanganSecara Bersama-Sama dengan Hasil Kemampuan Dribbling

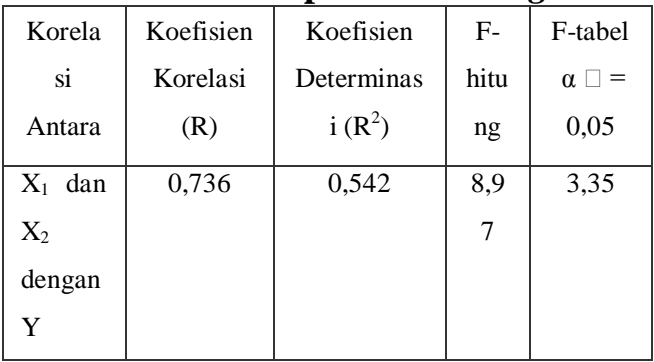


Keterangan:

regresi signifikan $\left(F_{h}=8,97>F_{t}=3,35\right)$.

Sebagaimana terlihat pada Tabel 9 di atas berdasarkan hasil perhitungan diperoleh koefisien korelasi didapat hasil $\mathrm{R}=0,736$, determinansi $\mathrm{R}^{2}$ sebesar 0,542 , dan $\mathrm{F}_{\text {hitung }}=$ $8,97>F_{\text {tabel }}=3,35$ pada taraf signifikansi $\alpha=0,05$. Dapat disimpulkan, bahwa koefisien korelasi ganda yang diperoleh dalam penelitian ini signifikan. Temuan ini menerima $\mathrm{H}_{\mathrm{a}}$, yakni Terdapat hubungan yang signifikan antara Kecepatan dan Koordinasi Mata Tangan secara bersama-sama dengan kemampuan dribbling Atlet Bolabasket Putra Klub NEO CLACH BukitTinggi, Konsekuensinya $\mathrm{H}_{0}$ ditolak.

Dengan koefisien korelasi ganda $\mathrm{R}$ sebesar 0,736, dan karena koefisien determinasinya $\left(\mathrm{R}^{2}\right)$ sebesar 0,542 , maka besar kontribusi kontribusi yang signifikan antara Kecepatan dan Koordinasi Mata Tangan secara bersama-sama adalah sebesar 54,2 \%. Ini artinya varians Kemampuan Dribbling sebagai variabel terikat memperoleh kontribusi secara bersamasama dari kedua variabel bebas, yaitu: Kecepatan dan Koordinasi Mata Tangan sebesar 54,2 \%. Dengan kontribusi sebesar $54,2 \%$, berarti selebihnya berasal dari kontribusi variabel lain sebagaimana dalam identifikasi masalah terdahulu.

\section{PEMBAHASAN}

Perhitungan kolerasi antara Kecepatan

\section{$\left(\mathrm{X}_{1}\right)$ dengan Kemampuan Dribbling (Y)} menggunakan rumus kolerasi product moment. Kriteria pengujian jika $t$ hitung $>t_{\text {tabel, }}$ maka terdapat hubungan yang signifikan dan sebaliknya (sudjana 1992:369). Dari hasil perhitungan kolerasi antara Kecepatan $\left(\mathrm{X}_{1}\right)$ dengan Kemampuan Dribbling (Y) diperoleh $t_{\text {hitung }} 2,03$ sedangkan $r^{2}=0,256$ pada taraf signifikan $\alpha=0,05$. Berarti dalam hal ini tingkat kontribusi Kecepatan $\left(\mathrm{X}_{1}\right)$ dengan Kemampuan Dribbling (Y) sebesar 25,6\%, dengan demikian semakin baik Kecepatan seseorang maka semakin baik pula Kemampuan Dribbling dalam bermain bolabasket.

Dari hasil analisis diatas dapat diambil kesimpulan bahwa terdapat hubungan yang signifikan antara Kecepatan dengan Kemampuan Dribbling. Kecepatan yang dimiliki sampel juga akan lebih baik dengan adanya latihan sehingga dengan proses latihan diharapkan Kecepatan semakin meningkat dan memberi pengaruh yang besar terhadap Kemampuan Dribbling.

Perhitungan kolerasi antara Koordinasi Mata Tangan $\left(\mathrm{X}_{2}\right)$ dengan Kemampuan 
Dribbling (Y) menggunakan rumus kolerasi product moment. Kriteria pengujian jika $t_{\text {hitung }}>$ $\mathrm{t}_{\text {tabel, }}$ maka terdapat hubungan yang signifikan dan sebaliknya (sudjana 2002:369). Dari perhitungan korelasi antara Koordinasi Mata Tangan dengan Kemampuan Dribbling diperoleh $t_{\text {hitung }} 3,48$ sedangkan $r^{2}=0,499$ pada taraf signifikan $\alpha=0,05$. Berarti dalam hal ini tingkat hubungan Koordinasi Mata Tangan dengan Kemampuan Dribbling sebesar 49,9\%, maksudnya semakin baik Koordinasi Mata Tangan seseorang maka semakin baik pula Kemampuan Dribbling.

Untuk mengetahui hubungan dari dua variabel atau lebih digunakan rumus korelasi ganda. Kriteria pengujian signifikan dengan uji $\mathrm{F}$ (Sudjana, 1992 : 385). Jika $F_{\text {hitung }}>F_{\text {tabel }}$ maka terdapat hubungan dan sebaliknya tidak terdapat hubungan jika $F_{\text {hitung }}<F_{\text {tabel. }}$ Dari hasil perhitungan diperoleh koefisien korelasi ganda (uji $\mathrm{F}$ ) didapat $\mathrm{F}_{\text {hitung }}=8,97$, sedangkan $\mathrm{F}_{\text {tabel }}$ diperoleh sebesar 3,35. Jadi $F_{\text {hitung }}>F_{\text {tabel }}$, selanjutnya hasil perhitungan $\mathrm{R}$ (korelasi berganda) secara bersama-sama tingkat hubungan Kecepatan $\left(\mathrm{X}_{1}\right)$ dan Koordinasi Mata Tangan $\left(\mathrm{X}_{2}\right)$ terhadap Kemampuan $\operatorname{Dribbling}(\mathrm{Y})$ sebesar 0,736 dan perhitungan $\mathrm{R}^{2}$ (square) atau koefisien determinan berganda memberikan sumbangan secara bersama-sama kedua variabel bebas ini $\left(\mathrm{X}_{1}\right.$ dan $\left.\mathrm{X}_{2}\right)$ terhadap Kemampuan Dribbling (Y) sebesar 54,2\%.

\section{SIMPULAN DAN SARAN}

\section{A. KESIMPULAN}

Berdasarkan hasil penelitian yang telah diuraikan pada bab terdahulu dapat dikemukakan kesimpulan sebagai berikut :

1. Hasil yang peroleh dari kecepatan mempunyai hubungan yang signifikan terhadap Kemampuan dribbling, ini ditandai dengan hasil yang diperoleh yaitu $\mathrm{t}_{\text {hitung }} 2,03$ $>t_{\text {tabel }} 1,76$, dengan nilai $r=0,506$ didapat $r^{2}$ $=0,256$, adapun besar kontribusinya adalah $25,6 \%$.

2. Hasil yang peroleh dari Koordinasi mata tangan mempunyai hubungan yang signifikan terhadap Kemampuan dribbling, ini ditandai dengan hasil yang diperoleh yaitu $\mathrm{t}_{\text {hitung }} 3,48$ $>t_{\text {tabel }} 1,76$, dengan nilai $r=0,707$ didapat $r^{2}$ $=0,500$, adapun besar kontribusinya adalah $50 \%$.

Terdapat hubungan yang signifikan secara bersama-sama antara kecepatan dan Koordinasi mata tangan terhadap Kemampuan dribbling. Diperoleh $F_{\text {hitung }} 8,97>F_{\text {tabel }} 3,35$, dengan nilai $\mathrm{R}=0,736$ didapat $\mathrm{R}^{2}=0,542$, adapun besar kontribusinya adalah $54,2 \%$.

Hubungan Kecepatan Dengan Kemampuan Dribbling ..... 37 Hendri Neldi 


\section{B. SARAN}

Maka penulis dapat memberikan saran-saran yang dapat membantu mengatasi masalah yang ditemui dalam pelaksanaan Kemampuan dribbling, yaitu :

1. Para pelatih disarankan untuk menerapkan dan memperhatikan tentang kecepatan dan koordinasi mata tangan dalam menjalankan program latihan, disamping factor-faktor lain yang ikut menunjang keberhasilan Kemampuan dribbling.

2. Para atlet agar memperhatikan faktor kecepatan dan koordinasi mata tangan untuk dapat melakukan latihan kondisi fisik yang lain di dalam menunjang kecepatan dan koordinasi mata tangan.

\section{DAFTAR PUSTAKA}

Arifin, Mochamad. (2004). Metoda Pelatihan Bolabasket Dasar, Surabaya, diktat.

Arikunto, Suharsimi. (2002). Prosedur Penelitian, Jakarta : PT RINEKA CIPTA.

Arsil. (2014). Pembinaan Kondisi Fisik. Padang : FIK NUP

Fardi, Adnan. 2000. Bola Basket Dasar. Padang: Fakultas Ilmu Keolahragaan UNP.

Nurhasan, 2001. Tes dan Pengukuran Dalam Pendidikan Jasmani. Jakarta : Direktorat Jendral Olahraga.

Oliver, Jon. (2007). Dasar-dasar Bolabasket, Bandung : Human Kinetics
Suharno HP, 2007. Ilmu Coaching Umum. Yogyakarta : Yayasan Sekolah

Undang-Undang Negara Repbulik Indonesia No.3 (2005). Sistem Keolahragaan Nasional. Jakarta. Menpora 